\title{
Histological alternation and vitellogenin induction in adult rare minnow (Gobiocypris rarus) after exposure to ethynylestradiol and nonylphenol
}

\author{
Jinmiao Zha ${ }^{a}$, Zijian Wang ${ }^{\mathrm{a}, *}$, Ning Wang ${ }^{\mathrm{b}}$, Chris Ingersoll ${ }^{\mathrm{c}}$ \\ ${ }^{a}$ State Key Laboratory of Environmental Aquatic Chemistry, Research Center for Eco-Environmental Sciences, \\ Chinese Academy of Sciences, P.O. Box 2871, Beijing 100085, PR China \\ b ASci Corporation, 4200 New Haven Road, Columbia, MO 65201, USA \\ ${ }^{\mathrm{c}}$ US Geological Survey, Columbia Environmental Research Center, 4200 New Haven Road, Columbia, MO 65201, USA
}

Received 6 January 2006; received in revised form 22 May 2006; accepted 31 May 2006

Available online 17 July 2006

\begin{abstract}
Adult rare minnow (Gobiocypris rarus) were exposed to $0,1,5$, and $25 \mathrm{ng} / 1$ (nominal concentrations) of $17 \alpha$-ethynylestradiol (EE 2 ) and 3,10 , and $30 \mu \mathrm{g} / 1$ (nominal concentrations) of 4-nonylphenol (NP) under flow-through conditions for a period of $28 \mathrm{~d}$. Low mortality was observed at 5 and $25 \mathrm{ng} / \mathrm{EE}_{2}$ and the growth of fish reduced significantly at $25 \mathrm{ng} / 1 \mathrm{EE}_{2}$ compared to controls. However, the gonadosomatic indices (GSI) of male fish were significantly higher in $1 \mathrm{ng} / 1 \mathrm{EE}_{2}$ treatments and in 10 and $30 \mu \mathrm{g} / \mathrm{l} \mathrm{NP}$ treatments $(p<0.05)$. Renal somatic indices (RSI) of male fish in $\mathrm{EE}_{2}$ treatments were significantly higher than those in controls $(p<0.05)$. In contrast, significantly decreased GSI and RSI of female fish could only be observed in 5 and $25 \mathrm{ng} / 1 \mathrm{EE}_{2}$ treatments $(p<0.05)$. Hepatosomatic indices (HSI) of male fish were significantly higher in $25 \mathrm{ng} / 1 \mathrm{EE} 2$ treatments. However, significantly increased of HSI of female fish could only be observed in $1 \mathrm{ng} / 1 \mathrm{EE}_{2}$ treatments. Plasma vitellogenin (VTG) induction could be observed in males after exposed to different concentrations of $\mathrm{EE}_{2}$ and $\mathrm{NP}$, and plasma VTG concentrations in females exposed to 5 and $25 \mathrm{ng} / 1 \mathrm{EE} 2$ were also significantly higher than in controls $(p<0.05)$. At level higher than $5 \mathrm{ng} / 1 \mathrm{EE}_{2}$ or $30 \mu \mathrm{g} / \mathrm{NP}$, hepatic tissue and renal tissue impairment of males could be observed. The pathological male liver was associated with a hypertrophy of hepatocytes and damages to cellar structure and accumulated eosinophilic material. Renal tissue showed different pathological effects which was reflected by accumulated eosinophilic material, hemorrhages within the kidney tubules and hypertrophy of the tubular epithelia. Also at these levels of exposure, feminization of male fish could be noticed and parts of males manifested the testis-ova phenomenon. Ovaries of female rare minnow in $25 \mathrm{ng} / 1 \mathrm{EE} 2 \mathrm{treat}-$ ment group were degenerated. Therefore when exposed to $\mathrm{EE}_{2}$ and NP even at environmental observed concentrations, adverse effects could occur in the reproductive system of adult fishes. The observed hepatic tissue and renal tissue impairment should be due to the induction and accumulation of VTG in organs, especially in males.
\end{abstract}

(C) 2006 Elsevier Ltd. All rights reserved.

Keywords: 17a-Ethynylestradiol; 4-Nonylphenol; Rare minnow (Gobiocypris rarus); Vitellogenin; Histopathology

\section{Introduction}

There has been a growing concern on possible harmful consequences of exposure to xenobiotic compounds that

\footnotetext{
* Corresponding author. Tel.: +86106284 9140; fax: +861062923543.

E-mail address: wangzj@rcees.ac.cn (Z. Wang).
}

are capable of modulating or disrupting the endocrine system of wildlife species (Ankley et al., 1998). The group of compounds, both natural and man-made, have the capacity to mimic the actions of the female steroids, and is very diverse and includes compounds belonging to the group of organochlorine pesticides, polychlorinated biphenyls, dioxins, alkylphenols, phthalates as well as natural or synthetic female steroids (Jobling et al., 1995). 
4-Nonylphenol (NP) reaches the aquatic environment as a degradation product of nonylphenol ethoxylates (NPE). The concentrations of NP within the aquatic environment vary. They have been found to ranged from $<0.2$ to $12 \mu \mathrm{g} / 1$ in polluted British river waters (Blackburn and Waldock, 1995), and $<0.3-45 \mu \mathrm{g} / 1$ in the Swiss river Glatt (Ahel et al., 1994). Several studies have been performed to evaluate the potential risk of NP exposure on the endocrine system, which include induction of the female specific egg yolk precursor vitellogenin in male rainbow trout (Oncorhynchus mykiss) (Jobling et al., 1996), development of testis-ova in medaka (Oryzias latipes), increasing of the ovosomatic index in medaka (Gray and Metcalfe, 1997).

The synthetic estrogen 17 a-ethynylestradiol $\left(\mathrm{EE}_{2}\right)$ is a chemical known for inducing vitellogenin in male individuals (Kime and Nash, 1999) and reduction of yolk filled occytes of mature females (Van den Belt et al., 2001). However, $\mathrm{EE}_{2}$ was observed extensive distribution in aquatic environment. The reported median concentration of $\mathrm{EE}_{2}$ ranged from 1 to $17 \mathrm{ng} / 1$ in sewage treatment effluents and ranged from below the detection limit to $15 \mathrm{ng} / \mathrm{l}$ in surface waters (Stumpf et al., 1996; Ternes et al., 1999).

$\mathrm{EE}_{2}$ and NP caused organ toxicity in fish, particularly in the liver and kidney, at relatively lower concentrations. Kidney impairment in fish based on the presence of eosinophilic material within renal tubule and tubule necrosis (Metcalfe et al., 2001; Lynn et al., 2003) and accumulated eosinophilic material and enlarged and changes in hepatocyte vacuolization in the liver have been reported recently (Metcalfe et al., 2001; Lynn et al., 2003). However, most of the work has been carried out with relatively high exposure concentration. In addition, there is a notable lack of studies that include histopathological examination of the gonads in adult, sexually mature fish after short-term exposure to endocrine disruptors, especially $\mathrm{EE}_{2}$ or synthetic analogues.

Rare minnow is a fish species of the largest family Cyprinidae. The fishes distribute mostly in upstream waters in the Yangtze River, Sichuan Province, China. The species has been used for aquatic toxicity testing in China (Zhou et al., 1995). The fish are small (30-80 $\mathrm{mm}$ in total length) and easy to culture in the laboratory. They have a relatively short life cycle, spawning hundreds of eggs with high fertilization and hatching rates. For adult, sex could be easily determined by secondary characteristics (Wang, 1992). Ma et al. (2004) have reported endocrine disrupting effects on Chinese rare minnow (Gobiocypris rarus) fed with field collected Limnodrilus sp.

The objectives of the present study were (1) to observe histopathological changes in adult rare minnow exposed to $\mathrm{EE}_{2}$ and NP at concentrations similar to those in the environment, (2) to build up the relationship of vitellogenin inducing and histological alteration, (3) to determine growth, mortality, gonadosomatic index, hepatosomatic index and renal somatic index, and organ impairs after $\mathrm{EE}_{2}$ or $\mathrm{NP}$ exposure.

\section{Material and methods}

\subsection{Chemicals}

Regent $17 \alpha$-ethinylestradiol $\left(\mathrm{EE}_{2}\right) \quad(98 \%$ purity) was obtained from Sigma (St. Louis, MO, USA). Technical nonylphenol (NP) was obtained from Sigma Aldrich (Deisenhofen, Germany). Technical nonylphenol consisted of $98 \%$ NP isomers ( $90 \% 4-\mathrm{NP}, 10 \% 2-\mathrm{NP})$ and $2 \%$ dinonylphenol. Stock solution of $\mathrm{EE}_{2}$ or NP was prepared by diluting the chemical in HPLC-grade acetone and mixing with distilled water, which was demineralized water. The final acetone concentration in the water was less than $0.01 \%$. To obtain the final concentration for exposure, the appropriate amount of the stock solution of $\mathrm{EE}_{2}$ and 4-NP was added to the aquarium water via a combination of polytetrafluorethylene (PFTE) and isoversinic tubes (Abimed, Langenfeld, Germany).

\subsection{Fish}

Rare minnow were provided by the Institute of Hydrobiology, the Chinese Academy of Sciences, China. The brood stock was kept in the follow-through de-chlorine tap water at $25 \pm 2{ }^{\circ} \mathrm{C}$ with a photoperiod of $16: 8 \mathrm{~h}$ (light: dark). Fish were generally fed with a commercial granule food (Trea, Germany) at a rate of $0.1 \%$ body weight per day and dry brine shrimp (Artemia) was supplemented for newly hatched fish.

\subsection{Exposure and experimental design}

Sexually mature rare minnow (about 7 months old) were the offspring from the same pair of brood stock. The body weights and body lengths were $1.4 \pm 0.4 \mathrm{~g}$ and $47.3 \pm$ $3.6 \mathrm{~mm}$, respectively. One day prior to the experiment, sex of all fish were determined by observing the shape of the abdomen and the distance between the abdomen fin and the stern fin (Wang, 1992). Fifteen males and 15 females were then randomly assigned to each of seven 30 1 glass tanks and acclimated for a week.

These fish were kept in the follow-through de-chlorine tap water $25 \pm 2{ }^{\circ} \mathrm{C}$ with a photoperiod of $16: 8 \mathrm{~h}$ (light: dark). Fish were generally fed with a commercial granule food (Trea, Germany) at a rate of $0.1 \%$ body weight per day and a dry diet of brine shrimp was supplemented. Waste and uneaten food were removed daily. After one week acclimation, fish were exposed to NP concentrations of 3,10 , or $30 \mu \mathrm{g} / 1$ and to $\mathrm{EE}_{2}$ concentrations of $0,1,5$, or $25 \mathrm{ng} / 1$ under flow-through conditions (flow rate of test solution was $10 \mathrm{l} / \mathrm{h}$ ) for $28 \mathrm{~d}$. Rare minnow exposed to $0.01 \%$ acetone for $28 \mathrm{~d}$ and all endpoints in $0.01 \%$ acetone treatment group have no significant difference with that of the control (de-chlorine water), Therefore, de-chlorine tap water was used for the controls in the results. There were no replicate chambers for each concentration. 
2.4. Tissue sampling and analyses after 4 weeks exposure to $N P$ and $E E_{2}$

\subsubsection{Measurement of plasma vitellogenin level}

Plasma vitellgenin level was measured using the carp vitellogenin ELISA kit (Bioscience, German). To avoid confounding results with sampling time, individual fish was taken sequentially from each treatment group. Fish were anesthetized in $200 \mathrm{ml}$ of de-chlorine tap water containing $200 \mathrm{mg} / 1 \mathrm{MS}-222$ (3-aminobenzoic acid ethyl ester methane sulfonate salt; Sigma, St. Louis, MO, USA, A-5040). Body length and wet body weight were determined. The root of the caudal fin of each fish was cut to collect blood with a heparinized microcapillary tube, and the blood volume was measured. The $250 \mu \mathrm{l}$ blood was transferred to the sampling buffer attached to the ELISA kit. Then the diluted blood specimen was immediately centrifuged $\left(8000 \mathrm{~g}, 10 \mathrm{~min}, 4^{\circ} \mathrm{C}\right)$ and frozen at $-80^{\circ} \mathrm{C}$ until use.

\subsubsection{Gonadosomatic, hepatosomatic and renal somatic indices}

Gonads, liver and kidney of each fish were removed and weighed after the blood was collected. Gonadosomatic index (GSI), hepatosomatic index (HSI) and renal somatic index (RSI) were calculated as following: GSI = gonad weights $(\mathrm{g}) /$ body weights $(\mathrm{g}) \times 100$; HSI $=$ liver weights $(\mathrm{g}) /$ body weights $(\mathrm{g}) \times 100$; RSI $=$ kidney weights $(\mathrm{g}) /$ body weights $(\mathrm{g}) \times 100$.

\subsubsection{Histological analysis}

After complete necropsy of all fish from all treatment and control groups, tissues of gonad, liver and kidney were removed, gonads (including testis and ovaries), livers and kidneys of male rare minnows were fixed in Bouin's Solution and buffered formalin (4\%), respectively, dehydrated and processed for paraffin wax embedding. The sections were cut at 3-4 $\mu \mathrm{m}$ and stained with hematoxiylin and eosin $(H \& E)$. The sections of the paraffin blocks were monitored microscopically.

\subsection{Statistics}

All statistical analyses were performed by using Statistica (version 99) (Sattsoft. Inc., USA). The experimental data were checked for homogeneity of variance across treatments by using Levene's test. When the assumptions were met, the data were subjected to one-way analysis of variance followed by Dunnett's multiple comparison tests. When no homogeneity was observed, the nonparametric Kruskal-Wallis test was used, followed by the MannWhitney $U$ test with Bonferroni's adjustment. Statistical significance was set at $p \leqslant 0.05$.

\section{Results and discussion}

\subsection{Mortality and growth}

After $28 \mathrm{~d}$ of exposure, the body weights and body lengths of rare minnow at $25 \mathrm{ng} / 1 \mathrm{EE}_{2}$ were significantly lower than those in control (Table 1). One and three fish died during the $28 \mathrm{~d}$ exposure period at $5 \mathrm{ng} / 1 \mathrm{EE}_{2}$ and $25 \mathrm{ng} / 1 \mathrm{EE}_{2}$, respectively (Table 2). In previous studies, the decreasing of total body length and weight of zebrafish (Danio rerio) was observed after $24 \mathrm{~d}$ exposure to $\mathrm{EE}_{2}$ at $10 \mathrm{ng} / 1$ (Van den Belt et al., 2002). In addition, Nimrod and Benson (1998) reported that newly hatched medaka (Oryzias latipes) fry exposed at $0.01 \mu \mathrm{g} / 1$ to $1.66 \mu \mathrm{g} / 1 \mathrm{EE}_{2}$ for $28 \mathrm{~d}$ followed by a post-dosing $28 \mathrm{~d}$ recover period significantly reduced their total body lengths and weights.

\subsection{Tissue somatic indices}

Tissue somatic indices, such as the gonadosomatic index (GSI), hepatosomatic index $\{\mathrm{HSI}\}$ and renal somatic index (RSI) are general measurements of the overall condition of fish or the growth status of a specific tissue (West, 1990). Tissue somatic indices are also commonly reported in fisheries studies because the indices can be easily determined and some indices such as the HSI can be an excellent predictor of adverse health in fish (Adams and McLean, 1985). In the present experiments, GSI of males exposed

Table 1

Growth, gonadosomatic index (GSI), hepatosomatic somatic index (HSI) and renal somatic index (RSI) of adult rare minnow at the end of NP and EE2 exposure period

\begin{tabular}{|c|c|c|c|c|c|c|c|c|c|c|}
\hline \multirow{2}{*}{$\begin{array}{l}\text { Exposure } \\
\text { concentrations }\end{array}$} & \multicolumn{2}{|c|}{ Body length (mm) } & \multicolumn{2}{|c|}{ Body weight (g) } & \multicolumn{2}{|l|}{ GSI $(\%)$} & \multicolumn{2}{|l|}{ HSI $(\%)$} & \multicolumn{2}{|l|}{ RSI (\%) } \\
\hline & Males & Females & Males & Females & Males & Females & Males & Females & Males & Females \\
\hline Control & $49.4 \pm 3.7^{\mathrm{a}}$ & $51.2 \pm 4.1$ & $1.4 \pm 0.3$ & $2.3 \pm 0.8$ & $3.4 \pm 2.1$ & $14.0 \pm 5.4$ & $2.3 \pm 0.8$ & $2.3 \pm 0.2$ & $0.5 \pm 0.5$ & $0.5 \pm 0.3$ \\
\hline $3 \mu \mathrm{g} / 1 \mathrm{NP}$ & $49.2 \pm 4.2$ & $51.6 \pm 3.8$ & $1.6 \pm 0.6$ & $2.4 \pm 0.6$ & $3.3 \pm 2.2$ & $12.4 \pm 4.3$ & $2.3 \pm 0.6$ & $2.7 \pm 0.2$ & $0.6 \pm 0.3$ & $0.6 \pm 0.2$ \\
\hline $10 \mu \mathrm{g} / 1 \mathrm{NP}$ & $49.7 \pm 3.4$ & $51.9 \pm 4.3$ & $1.5 \pm 0.5$ & $2.2 \pm 0.7$ & $4.0 \pm 1.5^{*}$ & $12.3 \pm 4.4$ & $2.7 \pm 0.5$ & $2.6 \pm 0.2$ & $0.7 \pm 0.4$ & $0.5 \pm 0.5$ \\
\hline $30 \mu \mathrm{g} / 1 \mathrm{NP}$ & $49.1 \pm 3.8$ & $51.0 \pm 3.5$ & $1.4 \pm 0.4$ & $2.1 \pm 0.5$ & $4.9 \pm 1.8^{*}$ & $13.4 \pm 5.2$ & $2.8 \pm 0.6$ & $2.1 \pm 0.4$ & $0.6 \pm 0.4$ & $0.6 \pm 0.4$ \\
\hline $1 \mathrm{ng} / 1 \mathrm{EE}_{2}$ & $50.0 \pm 4.2$ & $52.2 \pm 4.1$ & $1.5 \pm 0.5$ & $2.2 \pm 0.7$ & $5.6 \pm 0.8^{*}$ & $13.5 \pm 5.8$ & $2.8 \pm 0.7$ & $3.0 \pm 0.2^{*}$ & $1.0 \pm 0.4^{*}$ & $0.7 \pm 0.4$ \\
\hline $5 \mathrm{ng} / 1 \mathrm{EE}_{2}$ & $49.2 \pm 3.8$ & $51.1 \pm 3.2$ & $1.5 \pm 0.4$ & $2.1 \pm 0.8$ & $3.9 \pm 1.1$ & $9.1 \pm 5.0^{*}$ & $2.8 \pm 0.9$ & $2.3 \pm 0.3$ & $1.4 \pm 1.3^{*}$ & $1.3 \pm 0.4^{*}$ \\
\hline $25 \mathrm{ng} / 1 \mathrm{EE}_{2}$ & $47.4 \pm 3.2^{*}$ & $49.1 \pm 3.1^{*}$ & $0.9 \pm 0.6^{*}$ & $1.5 \pm 0.5^{*}$ & $3.8 \pm 1.2$ & $4.4 \pm 1.6^{*}$ & $3.5 \pm 0.7^{*}$ & $2.5 \pm 1.1$ & $2.6 \pm 1.4^{*}$ & $2.7 \pm 0.9^{*}$ \\
\hline
\end{tabular}

Asterisks indicate significant difference from the control $(p<0.05)$.

a Data expressed as mean $\pm \mathrm{SE}$. 
Table 2

Number of lesion gonads, liver and kidney of males by histological investigations at the end of NP and $\mathrm{EE}_{2}$ exposure period

\begin{tabular}{|c|c|c|c|c|c|c|}
\hline \multirow[t]{2}{*}{ Concentrations } & \multicolumn{2}{|c|}{$\begin{array}{l}\text { No. fish at the end of } \\
\text { exposure period }\end{array}$} & \multicolumn{2}{|c|}{ No. lesion gonad } & \multirow[t]{2}{*}{$\begin{array}{l}\text { No. males with } \\
\text { lesion liver }\end{array}$} & \multirow[t]{2}{*}{$\begin{array}{l}\text { No. males with } \\
\text { lesion kidney }\end{array}$} \\
\hline & Males & Females & Testes-ova & Degeneration & & \\
\hline Control & 15 & 15 & $0^{\mathrm{a}}$ & 0 & 0 & 0 \\
\hline $3 \mu \mathrm{g} / 1 \mathrm{NP}$ & 15 & 15 & 0 & 0 & 0 & 0 \\
\hline $10 \mu \mathrm{g} / 1 \mathrm{NP}$ & 15 & 15 & 0 & 0 & 4 & 0 \\
\hline $30 \mu \mathrm{g} / 1 \mathrm{NP}$ & 15 & 15 & 3 & 0 & 6 & 0 \\
\hline Control & 15 & 15 & 0 & 0 & 0 & 0 \\
\hline $1 \mathrm{ng} / 1 \mathrm{EE}_{2}$ & 15 & 15 & 1 & 0 & 6 & 2 \\
\hline $5 \mathrm{ng} / 1 \mathrm{EE}_{2}$ & 14 & 15 & 6 & 1 & 10 & 7 \\
\hline $25 \mathrm{ng} / 1 \mathrm{EE}_{2}$ & 13 & 14 & 9 & 5 & 13 & 12 \\
\hline
\end{tabular}

${ }^{a}$ Showed that this characters were not observed.

to 10 and $30 \mu \mathrm{g} / 1 \mathrm{NP}$ and $1 \mathrm{ng} / 1 \mathrm{EE}_{2}$ was significantly greater than that of control, whereas GSI of males exposed to 5 and $25 \mathrm{ng} / 1 \mathrm{EE}_{2}$ had no significantly effect compared to that of control. In addition, significantly lower GSI of female was only found at 5 and $25 \mathrm{ng} / 1 \mathrm{EE}_{2}$ (Table 1). This indicates that male is more sensitive to $\mathrm{EE}_{2}$ and NP exposure when GSI is used as endpoint. Increased GSI of male medaka might indicate the endocrine disruption effects while decreased GSI of female might due to ovaries degeneration (Scholz and Gutzeit, 2000). Scholz and Gutzeit (2000) reported GSI of male medaka was decreased at $\mathrm{EE}_{2}$ exposure levels of 10 and $100 \mathrm{ng} / \mathrm{l}$, respectively. Decreased GSI was also observed when male fathead minnows (Pimephales promelas) were exposed at 48 and $58.6 \mu \mathrm{g}$ NP/1 for $21 \mathrm{~d}$ (Harries et al., 2000).

Significantly higher HSI of males could only be observed at $25 \mathrm{ng} / \mathrm{l} \mathrm{EE_{2 }}$ treatments (Table 1). However, hepatosomatic indices (HSI) of female fish were significantly higher in $1 \mathrm{ng} / 1 \mathrm{EE}_{2}$ treatments. HSI of female fish in higher EE2 treatment group had no significantly effect compared with that of the control. The HSI for females and male in other treatments contained no statistically differences compared to control groups.

RSI of males was significantly higher in treatments at concentrations higher than $1 \mathrm{ng} / 1 \mathrm{EE}_{2}$ than that of control. For females, RSI of fish at 5 and $25 \mathrm{ng} / 1 \mathrm{EE}_{2}$ were significantly higher than that of control (Table 1). In NP treatments, no statistical significance between treatments and control of both male and female fish were found. The results suggest that renal tissue may be less affected by $\mathrm{NP}$ than by $\mathrm{EE}_{2}$.

In summary, the lowest-observed-effect concentrations (LOECs) calculated based on tissue somatic indices were $10 \mu \mathrm{g} / 1$ for NP and $1 \mathrm{ng} / 1$ for $\mathrm{EE}_{2}$ and the male rare minnow were generally more sensitive to the chemicals compared to female ones.

\subsection{Plasma vitellogenin (VTG) concentrations}

After $28 \mathrm{~d}$ of exposure to NP and $\mathrm{EE}_{2}$, plasma VTG concentrations of males ranged from $150 \mathrm{ng} / \mathrm{ml}$ plasma in the control to $620000 \mathrm{ng} / \mathrm{ml}$ plasma in $25 \mathrm{ng} / 1 \mathrm{EE}_{2}$ exposure group (Fig. 1), while plasma VTG concentrations of females ranged from $300000 \mathrm{ng} / \mathrm{ml}$ plasma in the control to $500000 \mathrm{ng} / \mathrm{ml}$ plasma at $25 \mathrm{ng} / 1 \mathrm{EE}_{2}$ (Fig. 1). Plasma VTG concentrations of male from all $\mathrm{NP}$ and $\mathrm{EE}_{2}$ treatments were significantly increased compared to controls. However, the plasma VTG concentrations of females increased significantly only in 5 and $25 \mathrm{ng} / 1 \mathrm{EE}_{2}$ treatments (Fig. 1).

There were evidences that $\mathrm{NP}$ and $\mathrm{EE}_{2}$ could induce the plasma VTG of male fish. Harries et al. (2000) reported that male fathead minnows exposed to $48.8-58.6 \mu \mathrm{g} / 1 \mathrm{NP}$ had plasma VTG levels 4000-45000 times higher than males in control. Increased VTG mRNA expression was observed in liver of male medaka after $7 \mathrm{~d}$ exposure to nominal 4-nonylphenol concentrations of 20 and $50 \mu \mathrm{g} / 1$ (Islinger et al., 2002). In adult male zebrafish, a $21 \mathrm{~d}$ exposure to $\mathrm{EE}_{2}$ at measured concentrations down to $5 \mathrm{ng} / 1$ caused significant increases in VTG formation in blood plasma (Van den Belt et al., 2001). A similar result was also obtained in a study which exposed adult zebrafish for $14 \mathrm{~d}$ to a nominal $\mathrm{EE}_{2}$ concentration of $5 \mathrm{ng} / \mathrm{l}$ and the level of VTG induction was roughly 3 -fold higher in female than in male zebrafish (Kime and Nash, 1999). In a recently study, Pawlowski et al. (2004) reported that the level of VTG of plasma of mature fathead minnow exposed to $1 \mathrm{ng} / \mathrm{l} \mathrm{EE} 2$ was significantly elevated. The present study indicates that concentrations of $3 \mu \mathrm{g} / 1 \mathrm{NP}$ or $1 \mathrm{ng} / 1 \mathrm{EE}_{2}$ could induce significant increase of plasma VTG of male rare minnows, suggesting that mature rare minnow was among the most sensitive species to endocrine disruptors.

\subsection{Histopathology}

\subsubsection{Gonads}

The histological changes of ovaries of all observed female fish over $28 \mathrm{~d}$ exposure to 3, 10, and $30 \mathrm{NP} u g / 1$ or 1 and $5 \mathrm{ng} / \mathrm{l}$ EE2 were similar to those in control (Fig. 2A). However, ovaries were severely degenerated when mature female rare minnow were exposed to $25 \mathrm{ng} / 1$ $\mathrm{EE}_{2}$ (Table 2, Fig. 2C). Histological inspection of the ovaries revealed all stages of occyte development including primary, secondary, and tertiary follicles at all exposure groups (Figs. 2A and C). 


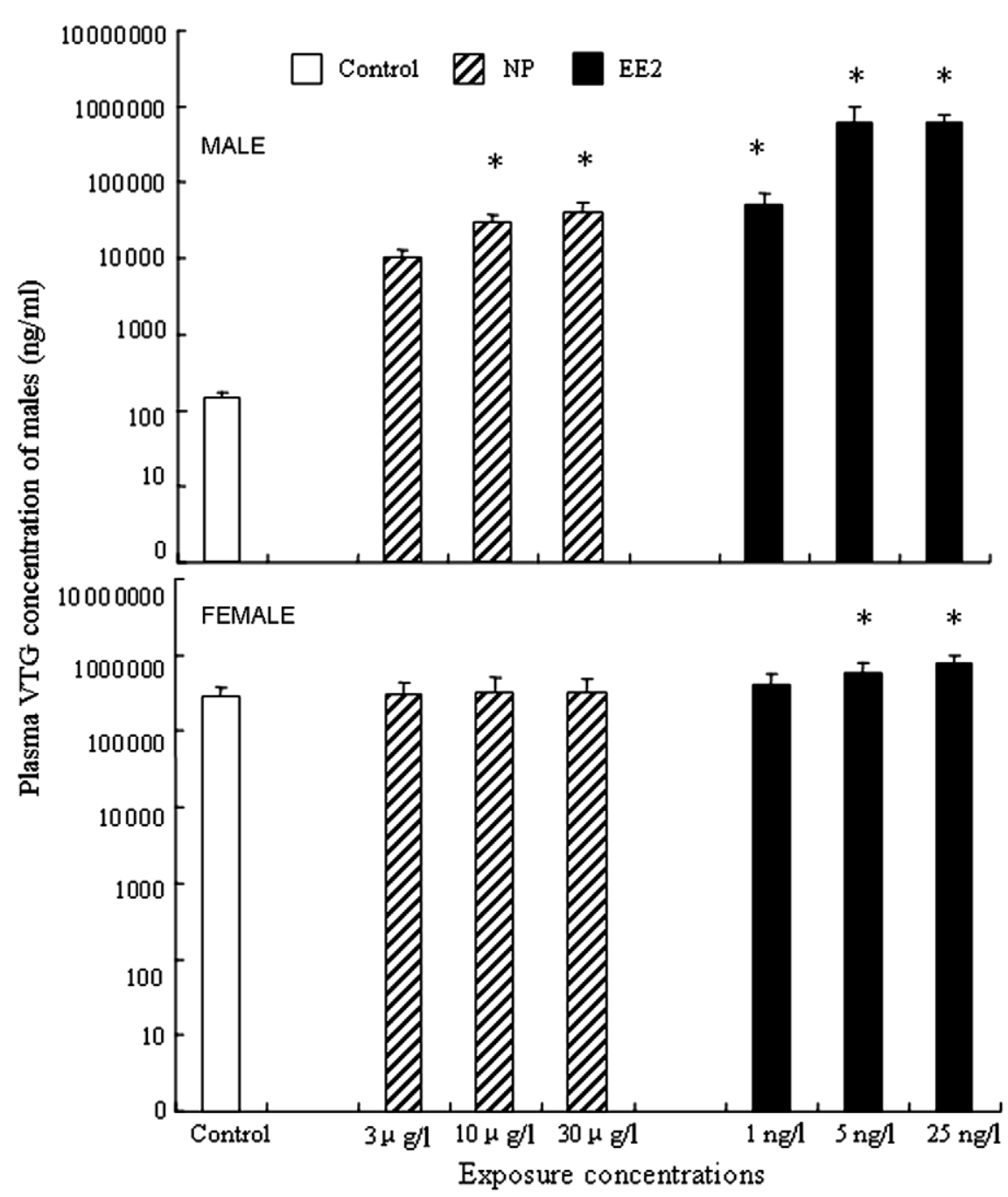

Fig. 1. Plasma VTG concentrations in mature male and female rare minnow after $28 \mathrm{~d}$ exposure to $\mathrm{EE}_{2}$ and NP. Asterisks indicate significantly difference from the control $(p<0.05)$. The error bars indicate standard deviation of the mean.

For fish in control, seminiferous tubules of testes were filled with large numbers of fertile sperm (Fig. 2B). In contrast, only primary and secondary spermatogonia could be detected and no more sperm were detectable at 5 and $25 \mathrm{ng} / 1 \mathrm{EE} 2$ and $30 \mu \mathrm{g} / 1 \mathrm{NP}$ treatment (Fig. 2D). In addition, occtyes were detected in testes at this level of observation (Table 2, Fig. 2D).

Testes-ova of mature rare minnow were detected at relatively low concentrations of $\mathrm{EE}_{2}$ and NP. However, some studies reported that other adult fish exposed to endocrine disruptors were not detected with testes-ova. For example, mature fathead minnow exposed to 10 and $100 \mathrm{ng} / 1$ EE2 could not be observed with testes-ova and only showed degeneration of gonads (Pawlowski et al., 2004). In addition, adult zebrafish exposed to $10 \mathrm{ng} / 1$ and $25 \mathrm{ng} / 1 \mathrm{EE} 2$ reduced the number of mature, yolk-filled oocytes (Van den Belt et al., 2001). In contrast, Gray and Metcalfe (1997) reported medaka larvae exposed for three months to NP at concentrations of 50 and $100 \mu \mathrm{g} / 1$ were shown to undergo testis-ova formation in males. Reinhard et al. (2001) also reported that long-term exposures resulted in formation of ova-testes and the appearance of sex reversals in fathead minnows after $305 \mathrm{~d}$ of exposure to EE2 at 4 ng/l. Gray and Metcalfe (1997) also reported that medaka with long-term exposure to p-nonylphenol at $50 \mu \mathrm{g} / 1$ caused the formation of ova-testes. This report showed a difference in adult fish with the formation of ova-testes at relatively low concentrations of endocrine disruptors. So our results showed that rare minnows were fish sensitive enough to screen endocrine disruptors.

\subsubsection{Hepatic tissue}

In male rare minnows, abundant cytoplasmic lipid in hepatocytes was observed in control and 3, $10 \mu \mathrm{g} / 1 \mathrm{NP}$ and $1 \mathrm{ng} / 1 \mathrm{EE} 2$ treatment (Fig. 3A). After $28 \mathrm{~d}$ of exposure, hepatic tissue of all male fish at $30 \mu \mathrm{g} / 1 \mathrm{NP}$ and $5,25 \mathrm{ng} / 1$ EE treatment showed hypertrophy of the hepatocytes and damaged cellar disarray, as well as an enlargement of the cell nuclei accompanied by a distinct reduction of glycogen deposits (Table 2, Fig. 3C). In addition, a lot of esinophilic material was observed to have accumulated in hepatic tissue (Fig. 3B). An increase in liver cell size detected in estra- 

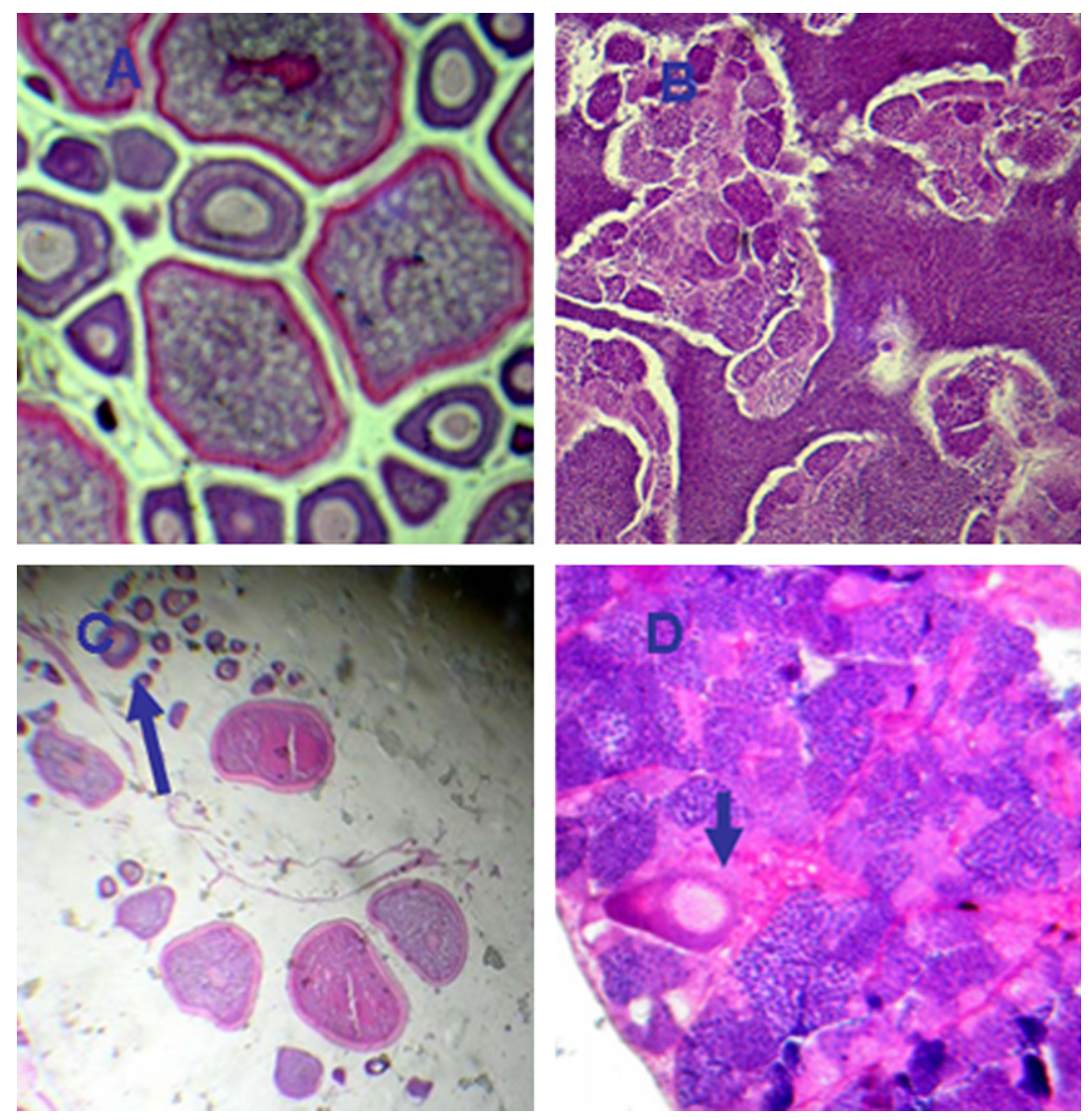

Fig. 2. Light micrographs of gonad tissue in adult rare minnow, stained with H\&E: (A) normal mature ovary from control ( $\times 100)$; (B) normal mature testis from control $(\times 400)$; (C) degeneration ovary from $25 \mathrm{ng} / 1$ EE2 exposure group $(\times 100)$; (D) ovay-testis from high dose EE2 and NP groups; arrow shows perinucleolar occytes $(\times 400)$.

diol-treated flounder was suggested to be the consequence of enhanced metabolic activity (Zaroogian et al., 2001) or the consequence of the stimulation of the vitellogenin synthesis when exposed to EE2 (Purdom et al., 1994). An estrogen-dependent depression in gluconeogenesis had been demonstrated in rainbow trout (Cevdet et al., 2003). A reduction of hepatic glycogen deposits observed in the present work has also been observed in estrogen-treated carp (Schwaiger et al., 2000) and flounder (Zaroogian et al., 2001). The results showed that endocrine disruptors caused hepatic tissue impairment of rare minnows due to inducing and accumulating VTG. We thought that inducing and accumulating VTG was a main reason for the impairing of hepatic tissue. However, the chronic toxicity of endocrine disruptors in relative environmental concentrations was only a secondary reason.

\subsubsection{Renal tissue}

In male rare minnows, normal renal tissues are composed of numerous renal corpuscles with well-developed glomeruli and system of tubules. The segment is lined with large, clear columnar epithelial cells with central nuclei and the brush border is reduced or non-existent (Table 3, Fig. 3D). Renal tissues of fish from all NP treatment and $1 \mathrm{ng} / 1 \mathrm{EE}_{2}$ treatment were shown to be normal. After exposed at $30 \mu \mathrm{g} / 1 \mathrm{NP}$ and 5, $25 \mathrm{ng} / 1 \mathrm{EE}_{2}$, lesions of renal tissue were characterized by severe hemorrhaging within the kidney tubules, the Bowman's space and the renal interstitium (Table 3, Fig. 3E). Distinct changes of the tubular epithelia could be observed, including hypertrophy, degeneration and necrotic of epithelia (Fig. 3F). In addition, we observed a lot of esinophilic material accumulated in the sinusoids of the head kidney (Fig. 3E). Accumulation of esinophilic material was reported in flounder injected with $10 \mathrm{mg} / \mathrm{kg} \mathrm{E}$ E $_{2}$ (Zaroogian et al., 2001). Esinophilic material was most probably VTG (Herman and Kincaid, 1988), synthesized under the stimulation of estrogenic chemicals such as $\mathrm{EE}_{2}$, and accumulated in various tissues. The hypertrophy and degenerative and necrotic of the tubular epithelia were observed in estrogen treated carp (Schwaiger et al., 2000) and flounder (Zaroogian et al., 2001). The results showed that renal tissue impairment of rare minnow was caused not only by chronic toxicity of endocrine disruptors but also by VTG accumulation. Therefore we concluded that renal impairment of fish exposed to relative environmental concentrations endocrine disruptors were mainly due to VTG accumulation.

In summary, synthetic steroids and synthetic analogues resulted in plasma vitelligenion concentrations increasing and gonadal sex reversal in adult rare minnows. Synthetic 

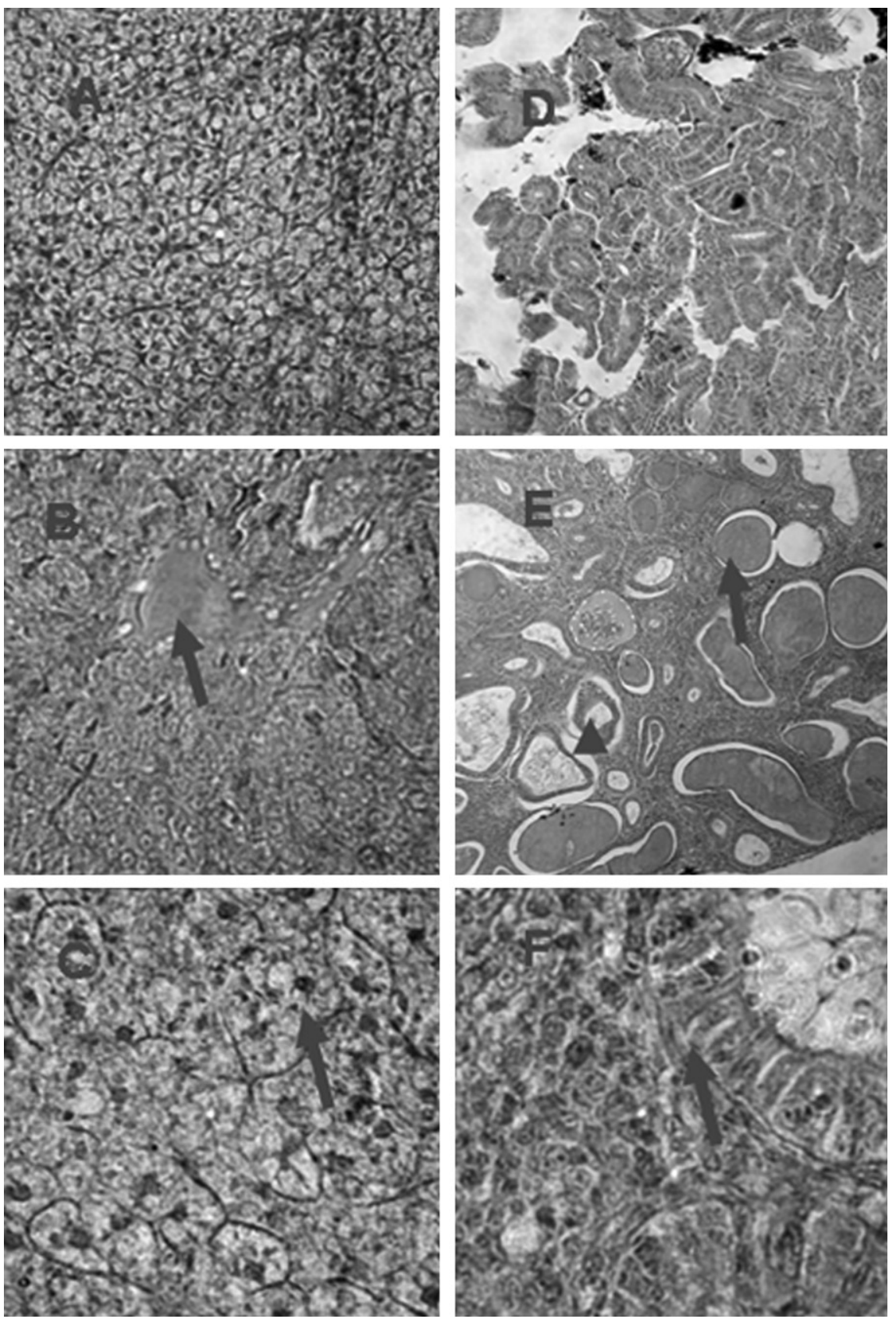

Fig. 3. Light micrograph investigation of hepatic and renal tissue of male adult rare minnow (HE, 400×): (A) normal hepatic tissue from the control; (B) hepatic tissue from $5 \mathrm{ng} / 1 \mathrm{EE}_{2}$ treatment group, showing accumulated eosinophilic material; (C) hepatic tissue from $25 \mathrm{ng} / \mathrm{l} \mathrm{EE}_{2}$ treated group showing swelling of hepatocytes and damaging with cell structure and enlargement of cell nuclei (arrow); (D) normal renal tissue; (E) renal tissue from 5 ng/1 treatment group (arrow and arrowhead shows hemorrhages within the lumen of kidney tubules and esinophilic material accumulated, respectively); (F) renal tissue from $25 \mathrm{ng} / \mathrm{l} \mathrm{EE}_{2}$ treated group (arrow shows necrotic of epithelia).

steroids $(1,5$, and $25 \mathrm{ng} / \mathrm{l} \mathrm{EE} 2)$ and synthetic analogues (3, 10 , and $30 \mu \mathrm{g} / 1 \mathrm{NP})$ induced significant increase of plasma VTG concentrations in male adult rare minnow. However, only relatively high exposure concentrations of synthetic steroids $(5,25 \mathrm{ng} / \mathrm{l}$ EE2) and synthetic analogues $(30 \mu \mathrm{g} / 1$ NP) induced testes-ova and caused severe lesions of liver with a hypertrophy of hepatocytes and damages to cellar structure and accumulated eosinophilic material and kidney by accumulated eosinophilic material, hemorrhages within the kidney tubules and hypertrophy of the tubular epithelia. Growth and tissue somatic indices were also sensitive endpoints. Since plasma VTG concentration changed and testes-ova were induced during the $\mathrm{NP}$ or $\mathrm{EE}_{2}$ exposure, hepatic and renal impairment might be due to the induction and accumulation of VTG in organs, especially in males. The finding would be useful for detecting endocrine disrupting activity with the rare minnow in laboratory studies as well as in the field. 


\section{Acknowledgements}

We gratefully acknowledge the support of National Basic Research Program of China (2003CB415005), Chinese Academy of Science (KZCX3-SW-431) and National Natural Science Foundation of China (40471129) for conducting this research.

\section{References}

Adams, S.M., McLean, R.B., 1985. Estimation of largemouth bass, Micropterus-salmoides Lacepede, growth using the liver somatic index and physiological variables. J. Fish Biol. 26, 111-126.

Ahel, M., Giger, W., Koch, M., 1994. Behaviour of alkylphenol polyethoxylate surfactants in the aquatic environment: I. Occurrence and transformation in sewage treatment. Water Res. 28, 1131-1142.

Ankley, G.T., Mihaich, E., Stahl, R., Tillitt, D., Colborn, T., McMaster, S., Miller, R., Bantle, J., Campbell, P., Denslow, N., Dickerson, R., Folmar, L., Fry, M., Giesy, J., Gray, L.E., Guiney, P., Hutchinson, T., Kennedy, S., Kramer, V., LeBlanc, G., Mayes, M., Nimrod, A., Patino, R., Peterson, R., Purdy, R., Ringer, R., Thomas, P., Touart, L., Van Der Kraak, G., Zacharewski, T., 1998. Overview of a workshop on screening methods for detecting potential (anti-)estrogenic: androgenic chemicals in wildlife. Environ. Toxicol. Chem. 17, 68-87.

Blackburn, M.A., Waldock, M.J., 1995. Concentrations of alkylphenols in rivers and estuaries in England and Wales. Water Res. 29, 1623-1629.

Cevdet, U., Mesude, I., Ayse, E., Belgin, I., Inci, T., 2003. The bioaccumulation of nonyphenol and its adverse effect on the liver of rainbow trout (Onchorynchus mykiss). Environ. Res. 92, 262-270.

Gray, M.A., Metcalfe, C.D., 1997. Induction of testis-ova in Japanese medaka (Oryzias latipes) exposed to $p$-nonylphenol. Environ. Toxicol. Chem. 16, 1082-1086.

Harries, J.E., Runnalls, T., Hill, E., Harris, C.A., Maddix, S., Sumpter, J.P., Tyler, C.R., 2000. Development of a reproductive performance test for endocrine disrupting chemicals using pair-breeding fathead minnows (Pimephales promelas). Environ. Sci. Technol. 34, 30033011.

Herman, R.L., Kincaid, H.L., 1988. Pathological effects of orally administered estradiol to rainbow trout. Aquaculture 72, 165-172.

Islinger, M., Yuan, H., Volkl, A., Braunbeck, T., 2002. Measurement of vitellogenin gene expression by RT-PCR as a tool to identify endocrine disruption in Japanese medaka (Oryzias latipes). Biomakers 7, 80-93.

Jobling, S., Reynolds, T., White, R., Parker, M.G., Sumpter, J.P., 1995. A variety of environmentally persistent chemicals, including some phthalate plasticizers, are weakly estrogenic. Environ. Health Persp. 103 (Suppl. 7), 582-587.

Jobling, S., Sheahan, D., Osborne, J.A., Matthiessen, P., Sumpter, J.P., 1996. Inhibition of testicular growth in Rainbow Trout (Oncorhynchus mykiss) exposed to estrogenic alkylphenolic chemicals. Environ. Toxicol. Chem. 15 (2), 194-202.

Kime, D.E., Nash, J.P., 1999. Gamete viability as an indicator of reproductive endocrine disruption in fish. Sci. Total. Environ. 233, $123-129$.
Lynn, P.W., Robert, L.H.J., David, M.J., 2003. Developmental estrogenic exposure in zebrafish (Danio rerio) II. Histological evaluation of gametogenesis and organ toxicity. Aquat. Toxicol. 63, 431-446.

Ma, T., Wang, Z., Liu, J., 2004. Endocrine disrupting effects on Chinese rare minnow (Gobiocypris rarus) fed with field collected Limnodrilus sp. J. Environ. Sci. 16, 784-787.

Metcalfe, C.D., Metcalfe, T.L., Kiparissis, Y., Brenda, G., Khan, C., Hughes, R.J., Croley, T.R., March, R., Potter, T., 2001. Estrogenic potency of chemicals detected in sewage treatment plant effluents as determined by in vivo assays with Japanese medaka (Oryzias latipes). Environ. Toxicol. Chem. 20, 297-308.

Nimrod, A.C., Benson, W.H., 1998. Reproduction and development of Japanese medaka following an early life state exposure to xenoestrogens. Aquat. Toxicol. 44, 141-156.

Pawlowski, S., van Aerle, R., Tyler, C.R., Braunbeck, T., 2004. Effects of 17a-ethinylestradiol in a fathead minnow (Pimephales promelas) gonadal recrudescence assay. Ecotoxicol. Environ. Saf. 57, 330-345.

Purdom, C.E., Hardiman, P.A., Bye, V.J., Eno, N.C., Tyler, C.R., Sumpter, J.P., 1994. Estrogenic effects of effluents from sewage treatment works. Chem. Ecol. 8, 275-285.

Reinhard, L., Thomas, H.H., Charlotte, P.C., Fred, S., Hermann, S., Peter, H., Grace, H.P., John, P.S., 2001. Effects of the synthetic estrogen 17a-ethinylestradiol on the life-cycle of the fathead minnow (Pimephales promelas). Environ. Toxicol. Chem. 20, 1216-1227.

Scholz, S., Gutzeit, H.O., 2000. 17-alpha-ethinylestradiol affects reproduction, sexual differentiation and aromatase gene expression of the medaka (Oryzias latipes). Aquat. Toxicol. 50, 363-373.

Schwaiger, J., Spieser, O.H., Bauer, C., Ferling, H., Mallow, U., Kalbfus, W., Negele, R.D., 2000. Chronic toxicity of nonylphenol and ethinylestradiol: haematological and histopathological effects in juvenile common carp (Cyprinus carpio). Aquat. Toxicol. 51, 69-78.

Stumpf, M., Ternes, T.A., Ilaber, K., Baumann, W., 1996. Determination of natural and synthetic estrogens in sewage plants and river water. Vom. Wasser. 87, 251-261.

Ternes, T.A., Stumph, M., Mueller, J., Haberer, K., Wilken, R.D., Servos, M., 1999. Behavior and occurrence of estrogens in municipal sewage treatment plants - I. Investigations in Germany, Canada and Brazil. Sci. Total Environ. 225, 81-90.

Van den Belt, K., Verheyen, R., Witters, H., 2001. Reproductive effects of ethynylestradiol and 4t-octylphenol on the zebrafish (Danio rerio). Arch. Environ. Contam. Toxicol. 41, 458-467.

Van den Belt, K., Wester, P.W., van der Ven, L.T.M., Verheyen, R., Witters, H., 2002. Effects of ethinylestradiol on the reproductive physiology in zebrafish (Danio rerio): time dependency and reversibility. Environ. Toxicol. Chem. 21, 767-775.

Wang, J., 1992. Reproductive biology of Gobiocypris rarus. Acta Hydrobiol. Sinica 16, 165-174.

West, G., 1990. Methods of assessing ovarian development in fishes - a review. Aust. J. Mar. Freshwater Res. 41, 199-222.

Zaroogian, G., Gardner, G., Borsay Horowitz, D., Gutjahr-Gobell, R., Haebler, R., Mills, L., 2001. Effect of $17 \beta$-estradiol,o, $p^{\prime}$-DDT, octylphenol and $p, p^{\prime}$-DDE on gonadal development and liver and kidney pathology in juvenile male summer flounder (Paralochthys dentatus). Aquat. Toxicol. 54, 101-112.

Zhou, Y., Cheng, S., Hu, W., Sun, M., 1995. A new toxicity test organismGobiocypris rarus. Zool. Res. 16, 59-63. 